JRPB, Vol. 7, No. 1, Maret 2019, Hal. 66-74

DOI: $10.29303 /$ jrpb.v7i1.98

ISSN 2301-8119, e-ISSN 2443-1354

Tersedia online di http://jrpb.unram.ac.id/

\title{
UJI KINERJA DAN ANALISIS EKONOMI MESIN PENANAM PADI (STUDI KASUS DESA MEKARLUYU, KECAMATAN SUKAWENING, KABUPATEN GARUT, JAWA BARAT)
}

Test Performance and Economic Analysis of Rice Transplanter (Case Study at Mekarluyu Village, Sukawening, Garut, West Java Province)

\author{
Wahyu Kristian Sugandi ${ }^{1, *}$, Handarto ${ }^{1}$, Totok Herwanto ${ }^{1}$, Chandra Irfan Hanif ${ }^{1}$ \\ ${ }^{1}$ Departemen Teknik Pertanian dan Biosistem, Fakultas Teknologi Industri Pertanian, \\ Universitas Padjadjaran
}

Email $^{*)}$ sugandiwahyu@gmail.com

Diterima: Desember 2018

Disetujui: Maret 2019

\begin{abstract}
Machine performance and economic analysis were parameters that capable on determining the operation feasibility of an engine in a business, especially paddy farming. The government through the Ministry of Agriculture had given Indo Jarwo 2:1 paddy transplanter machine to a paddy farmer group in Mekarluyu, Sukawening Garut. However, the performance and the economic analysis of the machine have not been tested technically. Therefore, it was necessary to conduct a study regarding the performance test and economic analysis of the machine, in order to determine its feasibility and its profitability, when it is applied by the farmer group of Mekarluyu region. The research was conducted from May to August 2017 in Mekarluyu, Garut Regency, West Java. The research aimed to conduct performance tests and economic analysis of paddy planting machines. Descriptive analysis was used by measuring the engine performance and the need of economic cost in the implementation of the jajar legowo cultivation system. The results of the economic analysis of Indo Jarwo 2:1 rice planting machines were BEP values 0.003 years/ha, BCR 1.63/ha/year, NPV 92,493,315.44, and IRR 96.86\%.
\end{abstract}

Keywords: Indo Jarwo 2:1, jajar legowo, business feasibility, paddy transplanter machine

\begin{abstract}
ABSTRAK
Kinerja sebuah mesin dan analisis ekonomi merupakan parameter yang mampu menentukan kelayakan operasi sebuah mesin pada suatu kegiatan usaha tani khususnya pertanian padi. Pemerintah melalui Kementrian Pertanian telah memberikan bantuan sebuah mesin penanam padi Indo Jarwo 2:1 kepada kelompok petani padi Desa Mekarluyu Kecamatan Sukawening Kabupaten Garut. Namun secara teknis mesin tersebut belum diuji baik kinerja mesinnya ataupun analisis ekonominya. Untuk itu, perlu dilakukan suatu penelitian berkenaan dengan uji kinerja dan analisis ekonomi mesin tersebut, sehingga mesin tersebut layak dan menguntungkan apabila diaplikasikan di kelompok tani Desa Mekarluyu. Penelitian ini
\end{abstract}


dilakukan pada bulan Mei sampai Agustus 2017 di Desa Mekarluyu, Kecamatan Sukawening, Kabupaten Garut, Jawa Barat. Tujuan dari penelitian ini adalah melakukan Uji kinerja dan melakukan analisi ekonomi mesin penanam padi. Adapun metode yang digunakan dalam penelitian ini adalah analisis deskriptif, yaitu mengukur dan menghitung kinerja aktual mesin di lapangan dan menganalisis kebutuhan biaya ekonomi mesin tersebut dalam kegiatan budidaya padi sistem jajar legowo. Hasil penelitian menunjukkan bahwa kapasitas kerja mesin penanam padi Indo Jarwo 2:1 adalah 0,04 ha/jam dengan daya yang dibutuhkan adalah sebesar $30 \mathrm{HP}$. Adapun hasil Analisis ekonomi dari mesin penanam padi indojarwo 2:1 adalah nilai BEP 0,003 tahun/ha, BCR 1,63/ha/tahun, NPV 92.493.315,44, dan IRR 96,86\%.

Kata kunci: Indo Jarwo 2:1, jajar legowo, kelayakan usaha, mesin penanam padi

\section{PENDAHULUAN}

Metode penanaman padi secara konvensional (tanam mundur, tandur) yang banyak diterapkan petani Indonesia untuk budidaya padi sawah di beberapa wilayah telah terhalang oleh berbagai macam kendala teknis pada proses yang berdampak pada hasil yang didapatkan (Kartasapoetra,1988). Beberapa kendala tersebut di antaranya adalah pergeseran tenaga kerja, kebutuhan waktu, kelayakan operasi, dan keakuratan di dalam penanaman sebagaimana yang dialami oleh petani di Desa Mekarluyu, Kecamatan Sukawening, Kabupaten Garut, Jawa Barat.

Pemerintah melalui Kementrian Pertanian telah memberikan solusi terhadap permasalahan yang dialami oleh petani Desa Mekarluyu dengan memberikan bantuan mesin penanam padi (rice tranplanter) Indo Jarwo. Namun pada kondisi nyata di lapangan, petani masih mengalami kesulitan di dalam menggunakan mesin tersebut karena tidak adanya pengawasan dan bimbingan instansi terkait secara intensif kepada para petani desa sehingga berpotensi menimbulkan kesalahan di dalam prosedur pelaksanaan yang dapat memberikan pengaruh terhadap hasil yang akan didapatkan.

Menurut Umar, dkk., (2017) Indo Jarwo transplanter adalah mesin modern untuk menanam bibit padi dengan sistem penanaman serentak 4 baris. Panjang mesin Indo Jarwo transplanter keseluruhan adalah 2,48 $\mathrm{m}$, lebar $1,70 \mathrm{~m}$, dan tinggi $86 \mathrm{~cm}$.
Motor penggerak yang digunakan motor bakar 4 langkah, daya 3,5 kW dan 4,6 HP, serta kecepatan putar 3600 rpm. Dalam sekali gerak perputaran roda, mesin ini dapat membuat 4 jalur dengan jarak antar jalur 20 - 40 - $20 \mathrm{~cm}$. Penggunaan mesin ini relatif mudah dimana garpu penanam (picker) mengambil bibit padi kemudian ditancapkan pada lahan yang kondisinya rata seperti yang disajikan pada gambar 1 .

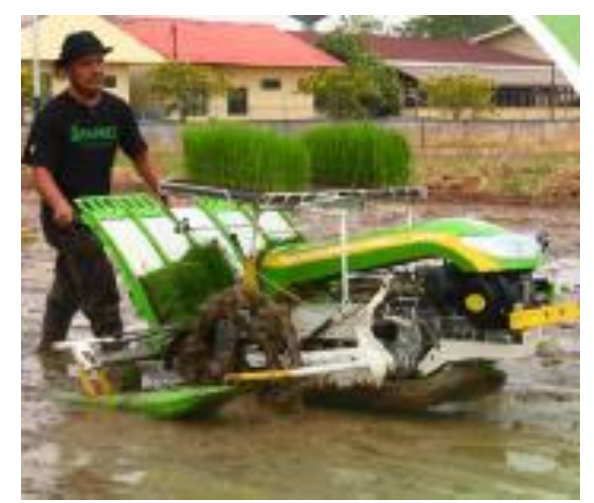

Gambar 1. Rice Transplanter Indo Jarwo

Pada dasarnya kelayakan penempatan suatu alat mesin pertanian di suatu daerah dipengaruhi oleh berbagai macam faktor penunjang kinerja mesin pada saat dioperasikan. Petani di Desa Mekarluyu menyatakan bahwa akan menerapkan metode berbasis mekanisasi ini apabila telah terlihat bukti secara nyata di lapangan, yaitu hasil dari nilai efektivitas dan efisiensi kinerja mesin serta perhitungan kelayakan ekonomi dari kegiatan yang dikerjakan. Oleh karena itu, perlu adanya suatu kajian berkenaan dengan uji kinerja dan analisis ekonomi yang dilakukan untuk mengatahui 
ketepatan penggunaan alat mesin rice transplanter di dalam mendukung kinerja dan mengatasi permasalahan yang dialami oleh para petani di Desa Mekarluyu.

\section{METODE PENELITIAN}

Metode yang digunakan adalah metode analisis deskriptif yaitu dengan cara melakukan melakukan survey lapangan, mengidentifikasi permasalahan di kelompok tani dan memberikan solusi terhadap permasalahan yang ada, terutama kesesuaian penerapan mesin penanam padi indo jarwo dilapangan yang meliputi pengukuran, pengamatan, perhitungan, menganalisis, menguji, dan mengevaluasi tingkat kelayakan mesin penanam padi serta studi literatur.

\section{Alat dan Bahan}

Alat yang digunakan untuk penelitian ini adalah cone penetrometer (diameter cone $2 \mathrm{~cm}$ ), gelas ukur (Herma $250 \mathrm{ml}$ ), jangka sorong (ketelitian 0,005 mm), kalkulator, kamera, laptop, meteran (ketelitian 0,5 mm), penggaris (ketelitian $0,05 \mathrm{~cm}$ ), sound level meter (Krisbow KW06-291), stopwatch (ketelitian 1/100 detik), tachometer (Hioki 3402), dan timbangan (beban maksimal 150 $\mathrm{kg})$.

Bahan yang digunakan dalam penelitian ini adalah benih padi Inpari 42, lahan sawah dengan jenis tanah pedsolik merah kuning, dan bahan bakar solar untuk menggerakkan mesin penanam indo jarwo.

\section{Tahapan Penelitian}

\section{$\underline{\text { Uji Kinerja }}$}

Uji kinerja yang dilakukan meliputi identifikasi kondisi lahan, kondisi bibit uji, kondisi pengaturan mesin, kinerja mesin, dan uji pelayanan. Parameter pengujian mesin didasarkan pada RNAM (Regional Network of Agriculture Machinary) Test Code Procedure, SNI (Standar Nasional Indonesia), dan ditambah dengan hasil dari Test Report Kementerian Pertanian untuk mesin penanam bibit padi.

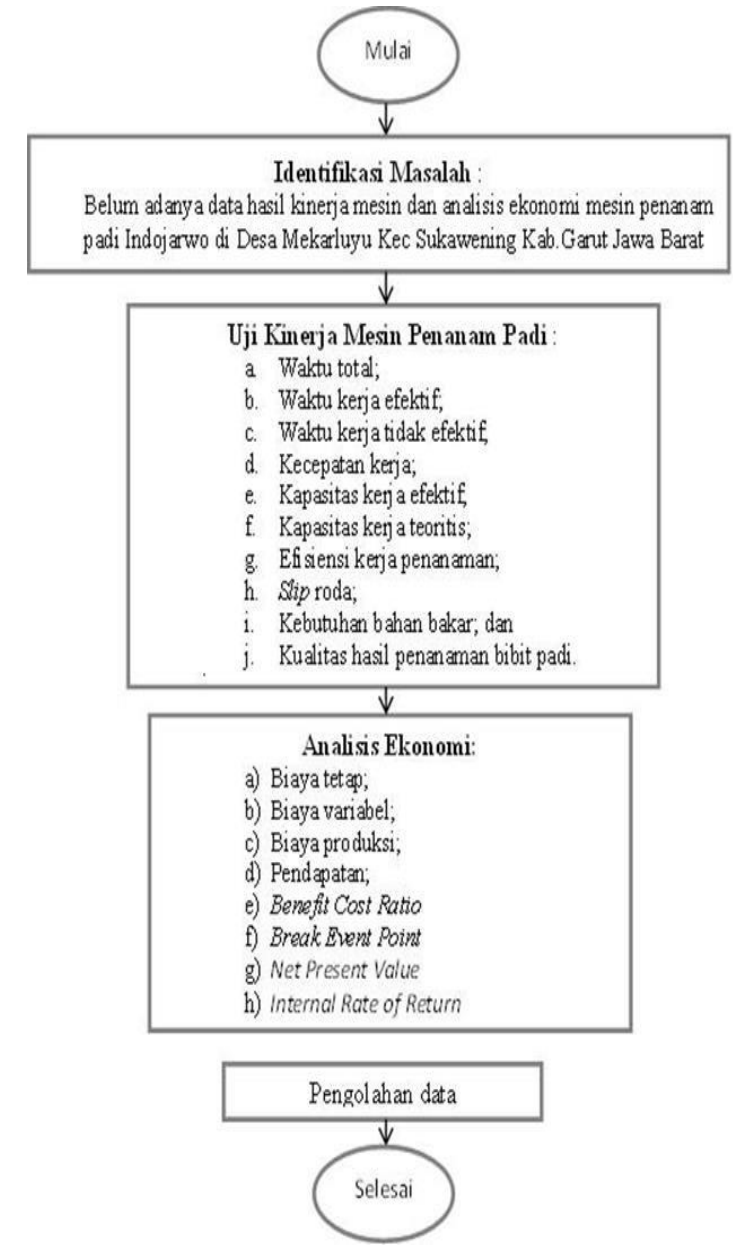

Gambar 2. Diagram Alir Uji Kinerja

\section{Analisis Ekonomi}

Adapun prosedur pengukuran uji kinerja adalah sebagai berikut :

a) Waktu total dihitung menggunakan Persamaan $\mathrm{t}_{\mathrm{t}}=\mathrm{t}_{\mathrm{a}}+\mathrm{t}_{\mathrm{b}}$ yang didasarkan pada pengukuran waktu kerja efektif dan waktu kerja tidak efektif (SNI 7607: 2013).

b) Waktu kerja dihitung menggunakan Persamaan $t_{e}=t_{t}-t_{b}$ yang didasarkan pada pengukuran waktu kerja total dan waktu kerja tidak efektif (Herwanto, dkk., 2016).

c) Waktu kerja tidak efektif diukur saat berbelok, penyetelan, perbaikan, dan pengisian bibit. (SNI 7607: 2013).

d) Kecepatan kerja teoritis dihitung menggunakan Persamaan (Widata, 2015). $\mathrm{v}_{\mathrm{a}}=\frac{\mathrm{s}_{\mathrm{t}}}{\mathrm{t}}$ 
e) Kapasitas kerja aktual dihitung menggunakan Persamaan

$\mathrm{KK}_{\mathrm{a}}=\frac{\mathrm{A}}{\mathrm{t}_{\mathrm{t}}}$

f) Kapasitas kerja teoritis dihitung menggunakan Persamaan

$\mathrm{v}_{\mathrm{t}}=\frac{\mathrm{v}_{\mathrm{a}}}{(1-\text { slip })}$,

dan

$\mathrm{KK}_{\mathrm{t}} 0,36 \times \mathrm{L} \times \mathrm{v}_{\mathrm{t}}$

g) Efisiensi kerja penanaman dihitung menggunakan Persamaan

$\mathrm{E}=\frac{\mathrm{KK}_{\mathrm{e}}}{\mathrm{KK}_{\mathrm{t}}} \times 100 \%$.

h) Slip roda diselesaikan dengan cara menghitung dengan menggunakan Persamaan

$\mathrm{S}_{\mathrm{r}}=100 \times \frac{\mathrm{L}_{1}-\mathrm{L}_{2}}{\mathrm{~L}_{1}}$

dan

$\mathrm{L}_{1}=\pi \times \mathrm{D} \times \mathrm{n}$

i) Lebar kerja penanaman diperoleh dengan pengukuran langsung.

j) Kebutuhan bahan bakar dihitung menggunakan Persamaan

$\mathrm{F}_{\mathrm{c}}=\frac{\mathrm{F}_{\mathrm{v}}}{\mathrm{t}_{\mathrm{wp}}}$

k) Kebutuhan daya dihitung dengan Persamaan (Abdullah, dkk., 1990):

$\mathrm{ELP}=\frac{(\mathrm{KL} \times \mathrm{CL})}{\mathrm{CE}}$

Adapun prosedur analisis ekonomi adalah sebagai berikut (Kastaman, 2004):

a. Biaya tetap dihitung menggunakan Persamaan (Kastaman, 2004):

$\mathrm{BT}=\mathrm{D}+\mathrm{H}+\mathrm{M}+\mathrm{T}$

b. Biaya Variabel dihitung menggunakan Persamaan :

$\mathrm{BV}=\mathrm{BPT}+\mathrm{B}_{\mathrm{tn}}+\mathrm{BP}_{\mathrm{tn}}+\mathrm{BPn}$

c. Biaya produksi dihitung menggunakan Persamaan :

$\mathrm{BP}=\mathrm{BT}+\mathrm{BV}$

d. Break Event Point dihitung menggunakan Persamaan (Ariyanti, dkk., 2014):

$\mathrm{BEP}=\frac{\mathrm{BT}}{\mathrm{R}-\mathrm{BV}}$

e. Benefit Cost Ratio (BCR) dihitung menggunakan Persamaan: (Kastaman, 2004)
$\mathrm{BCR}=$

$\sum$ Nilai Sekarang pendapatan

$\overline{\Sigma \text { Nilai Sekarang pengeluaran }}$

f. Net Present Value dihitung menggunakan Persamaan: (Kastaman, 2004)

$\mathrm{NPV}=\frac{\mathrm{KK}_{\mathrm{e}}}{\mathrm{KK}_{\mathrm{t}}} \times 100 \%$.

g. Internal Rate of Return dihitung dengan menggunakan Persamaan: (Kastaman, 2004)

$I R R=i_{1}-N P V_{1} \frac{\left(i_{2-i_{1}}\right)}{\left(N V_{2}-N P V_{1}\right)}$

\section{HASIL DAN PEMBAHASAN}

\section{Hasil Uji Kinerja Mesin Penanam Padi}

Adapun Hasil Uji kinerja mesin Penanam Padi seperti yang tersaji pada tabel 1.

Tabel 1. Hasil Uji Kinerja Mesin Penanam Padi

\begin{tabular}{lll}
\hline No & $\begin{array}{l}\text { Parameter yang } \\
\text { di ukur }\end{array}$ & Nilai \\
\hline 1 & $\begin{array}{l}\text { Kapasitas Kerja Aktual } \\
\text { Rata-Rata }\end{array}$ & 0,04 ha/jam \\
2 & $\begin{array}{l}\text { Lebar Kerja Teoritis } \\
\text { Rata-Rata }\end{array}$ & $120 \mathrm{~cm}$ \\
3 & Kecepatan Kerja Aktual & $1,2 \mathrm{~km} / \mathrm{jam}$ \\
& Rata-Rata & $22,56 \%$ \\
4 & Effisiensi & $25,89 \%$ \\
5 & Slip Roda & $44,18 \mathrm{liter} / \mathrm{ha}$ \\
6 & Kebutuhan Bahan Bakar & $29,59 \mathrm{HP}$ \\
7 & Kebutuhan Daya &
\end{tabular}

Berdasarkan berdasarkan Tabel 1 dapat dinyatakan bahwa kinerja mesin dalam melakukan pekerjaan terkategorikan ke dalam kinerja yang tidak optimal karena memiliki efisiensi yang rendah walaupun kondisi penunjang hampir seluruhnya dapat dikondisikan. mesin penanam hanya memiliki kapasitas kerja sebesar 0,04 ha/jam $(22,42 \mathrm{jam} / \mathrm{ha})$. Nilai tersebut menunjukkan bahwa mesin baru mampu menyelesaikan pekerjaan penanaman petakan sawah seluas 1 ha dalam waktu 22,12 jam (3 hari kerja). Perolehan nilai tersebut berdampak langsung kepada nilai efisiensi kerja mesin yang memiliki persentase $30,8 \%$, dan nilai kebutuhan bahan bakar yang menunjukkan 
1,87 1/jam (41,35 1/ha). Ketiga nilai pada tiga parameter tersebut apabila dibandingkan dengan test report untuk mesin yang sama memiliki perbedaan nilai yang signifikan. Pada data test report mesin mampu memperoleh kapasitas kerja 0,20 ha/jam (5,05 jam/ha), dengan nilai efisiensi $64,43 \%$ dan kebutuhan bahan bakar 1,24 $1 /$ jam $(6,25$ 1/ha).

Nilai pada data tersebut menjadi alasan kenapa kinerja mesin penanam Indo Jarwo terkategorikan ke dalam kinerja yang tidak baik di daerah pengujian, karena idealnya mesin mampu menyelesaikan tugas penanaman dengan kapasitas 5,05 jam/ha. Namun pada kenyataannya, mesin baru mampu menyelesaikan pekerjaan dengan kapasitas 22,42 jam/ha. Rentang perbedaan nilai yang mencatatkan perbedaan hampir $80 \%$ di antara keduanya berdampak pada meningkatnya pemenuhan kebutuhan operasional mesin, seperti kebutuhan bahan bakar dan upah kerja operator. Slip memiliki pengaruh yang sangat besar kepada seluruh parameter uji kinerja ini, dengan nilai sebesar 25,90\% slip terbukti mampu menurunkan jarak tempuh dengan waktu yang dibutuhkan sehingga berdampak pada kemampuan mesin menyelesaikan pekerjaannya.

Besarnya perbedaan nilai disebabkan oleh dua faktor, dimana yang pertama adalah kondisi lahan. Desa Mekarluyu memiliki karakteristik lahan dengan kedalaman rata-rata $32,2 \mathrm{~cm}$ pada kondisi setelah bajak, dimana seperti yang telah dijelaskan sebelumnya kondisi tersebut langsung berdampak pada besarnya nilai slip yang terbukti berada pada persentase sebesar $25,90 \%$. Selain daripada itu, nilai ground pressure mesin yang lebih besar jika dibandingkan dengan cone index juga menjadi penyebab rendahnya kapasitas kerja karena besarnya potensi amblas. Faktor kedua yang menjadi penyebab adalah keterbatasan kemampuan operator dalam mengoperasikan alat pada kedalaman yang tinggi, karena hal tersebut berdampak langsung kepada kecepatan kerja yang seharusnya bisa dipenuhi untuk menunjang kinerja mesin. Jika dibandingkan dengan data pada test report, mesin mampu dioperasikan dengan kecepatan 2,71 km/jam pada kecepatan putar $3600 \mathrm{rpm}$.

Besarnya nilai slip juga memberi pengaruh terhadap kebutuhan daya, dimana tercatat parameter tersebut bernilai 29,54 HP. Nilai tersebut menunjukkan bahwa dengan persentase slip $25,90 \%$ mesin membutuhkan daya hampir tiga kali lipat dari kondisi awal yaitu sebesar 5,5 HP. Namun, kapasitas kerja mesin penanam tetap memiliki nilai yang lebih baik jika dibandingkan dengan cara manual yang bernilai $50 \mathrm{jam} / \mathrm{ha}$, sehingga potensi pengembangan mesin penanam masih dapat dilakukan. Pengkondisian lahan dan peningkatan kemampuan operator melalui pelatihan khusus merupakan hal yang dapat dilakukan untuk memperbaiki rendahnya nilai efisiensi yang dimiliki mesin.

\section{Kualitas Hasil Penanaman}

Kualitas hasil penanaman (Tabel 2) merupakan parameter yang menunjukkan tingkat mutu dari perbandingan hasil yang dituju dengan hasil yang sebenarnya diperoleh di lapangan. Pada parameter ini dinilai apakah mesin mampu menyelesaikan penanaman sesuai dengan penyetelan awal yang ditujukan oleh operator.

Tabel 2. Kualitas Hasil Penanaman

\begin{tabular}{cll}
\hline No & $\begin{array}{l}\text { Parameter yang } \\
\text { di ukur }\end{array}$ & Nilai \\
\hline 1 & Kedalaman Rata-Rata & $2,9 \mathrm{~cm}$ \\
2 & Jarak Tanam & $14,4 \mathrm{~cm}$ \\
3 & Jumlah Bibit Tiap & 2 bibit/rumpun \\
& Rumpun & \\
4 & Kebutuhan Bibit & $320 \mathrm{kotak} / \mathrm{ha}$ \\
5 & Sudut Ketegakkan & $75^{\circ}$ \\
& Tanaman & \\
6 & $\begin{array}{l}\text { Presentasi Lubang } \\
\text { Tosong }\end{array}$ & 2,30 \% \\
7 & Presentasi Bibit Rebah & $2,90 \%$ \\
\hline
\end{tabular}

Parameter kedalaman tanam rata-rata dan jumlah bibit tiap rumpun rata-rata mencapai kualitas yang sangat baik karena nilai yang mampu diperoleh mesin dapat mecapai kondisi penyetelan mesin yang 
diinginkan, yaitu kedalaman tanam $3 \mathrm{~cm}$ dengan jumlah bibit 2-3 bibit per lubangya. Kondisi tersebut dapat tercapai karena kerja dari jari penanam tidak dipengaruhi oleh kondisi lahan yang ada, sehingga apabila penyetelan sudah dilakukan sesuai dengan kondisi yang diinginkan maka dua parameter tersebut dapat dikondisikan pada keadaan ideal.

Hasil berbeda ditunjukkan pada parameter jarak tanam dalam baris rata-rata, dimana mesin yang telah dikondisikan untuk dapat menanam dengan jarak tanam dalam baris rata-rata $18 \mathrm{~cm}$ namun pada kenyataannya mesin menanam dengan jarak rata-rata $14,4 \mathrm{~cm}$. Rentang perbedaan mencapai $3,6 \mathrm{~cm}$ di antara kedua nilai tersebut disebabkan oleh $25,90 \%$ slip yang terjadi pada saat mesin dioperasikan di atas lahan. Slip memiliki pengaruh besar terhadap jarak tanam yang dihasilkan oleh mesin, karena jari penanam akan terus konstan melakukan pergerakan menanam benih di saat mesin kehilangan jarak tempuh karena roda tidak mendapatkan traksinya. Ketidaksesuaian jarak tanam yang diperoleh akan memberikan dampak pada pertumbuhan tanaman, karena akan berpotensi menimbulkan persaingan antar tanaman untuk memperoleh unsur hara dan sinar matahari.

Selain itu, tujuan mengkondisikan tanaman untuk berada pada jarak tanam 18 $\mathrm{cm}$ dalam baris dan $20 \mathrm{~cm}$ antar barisnya pada sistem budidaya jajar legowo 2:1 adalah agar suhu dan kelembaban udara berada pada kondisi ideal tidak dapat tercapai karena rumpun tanaman padi menjadi sangat padat antara baris dan lubangnya. Pada parameter kebutuhan bibit, mesin mencatatkan kebutuhan 320 kotak per ha yang dimana nilai tersebut merupakan catatan yang tidak baik karena jika dibandingkan dengan kebutuhan bibit pada test report dengan kondisi jarak tanam antar baris $15 \mathrm{~cm}$, mesin hanya membutuhkan 286 kotak per ha.

\section{Hasil Uji Pelayanan Mesin Penanam Padi}

Selama dilaksanakan pengujian mesin penanam bibit padi (rice transplanter) Merk Crown model jajar legowo 2:1 di lahan sawah mengalami kesulitan dalam pengoperasiannya. Mesin terlalu banyak mengalami slip sehingga operator sangat sulit mengendalikan mesin untuk tetap berjalan lurus sesuai dengan lintasan sehingga jarak tanam menjadi tidak sesuai dengan penyetelan yang dilakukan. Selain itu, tidak terbiasanya operator mengoperasikan mesin di lahan dengan kedalaman yang tinggi menjadi faktor kendala lainnya. Kendala selanjutnya yang dialami operator adalah minimnya fungsi kopling belok pada saat operator membelokkan mesin di bagian headland. Hal tersebut dikarenakan lahan uji memiliki kedalaman di atas $30 \mathrm{~cm}$ sehingga sangat sulit satu roda mendapatkan traksi untuk kemudian mampu membelokkan mesin. Untuk tingkat kebisingan mesin diperoleh rata-rata kebisingan sebesar 81,19 dB. Jika dibandingkan dengan nilai ambang batas menurut Kepmennaker Nomor 51 Tahun 1999, mesin masih berada pada kategori aman karena nilai kebisingan masih di bawah nilai ambang batas kebisingan selama 8 jam per hari yaitu sebesar $85 \mathrm{~dB}$.

\section{Hasil Analisis Ekonomi \\ Biaya Tetap}

Berdasarkan pada perhitungan, biaya depresiasi yang dibutuhkan yaitu sebesar Rp 7.714.286/tahun dengan umur pakai 7 tahun. Walaupun mesin merupakan pemberian pemerintah terhadap petani Desa Mekarluyu sehingga tidak terdapat resiko kehilangan nilai atas investasi petani di dalamnya, namun biaya depresiasi tetap dihitung karena nilai tersebut ditujukan untuk rencana apabila mesin mengalami kerusakan total dan petani membutuhkan sebuah mesin penanam baru untuk didatangkan. Untuk kebutuhan biaya tempat atau bangunan, perawatan dan pemeliharan, serta pajak mesin mencatatkan kebutuhan sebesar $\mathrm{Rp}$ 600.000/tahun, Rp 720.000/tahun, dan Rp 1.200.000/tahun dengan asumsi perhitungan 
biaya tempat atau bangunan sebesar $1 \%$ dari harga awal mesin, perawatan dan pemeliharaan $1,2 \%$ dari harga awal mesin, dan $2 \%$ pajak dari harga awal mesin, sehingga total biaya tetap yang dibutuhkan mesin adalah sebesar Rp 10.234.285/tahun. Jika dibutuhkan biaya tetap sebesar Rp 10.234.286/tahun maka setidaknya petani harus memenuhi kebutuhan biaya sebesar Rp 852.857/bulan, atau sekitar Rp 3.411.429/musim tanam.

\section{Biaya Variabel}

Mesin penanam membutuhkan biaya

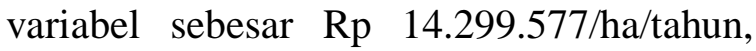
lebih rendah dibandingkan biaya variabel cara tandur yang memiliki kebutuhan sebesar Rp 14.929.894/ha/tahun. Biaya variabel dengan mesin penanam lebih sedikit karena mesin penanam mampu mengerjakan pekerjaan lebih cepat karena kapasitas kerja yang lebih baik. Hal tersebut berdampak langsung pada biaya penananaman yaitu sebesar Rp 1.949.048/ha/tahun. Biaya operator mesin penanam adalah sebesar Rp 413.386/tahun sedangkan cara tandur sebesar 1.984.127/tahun. Harga tersebut mampu menutupi kebutuhan biaya benih dan biaya bahan bakar mesin penanam yang apabila dijumlahkan memiliki nilai sebesar Rp 1.048.307.

\section{Biaya Produksi}

Berdasarkan biaya variabel mesin penanam, maka biaya produksi yang ideal adalah mengasumsikan bahwa biaya tetap dibayar seluruh anggota kelompok tani yang berjumlah 130 orang sehingga menjadi $\mathrm{Rp}$ 78.726 per tahun. Keadaan tersebut mampu menjadikan peran serta mesin penanam memiliki catatan kebutuhan biaya produksi yang lebih baik yaitu sebesar Rp 14.378.253/tahun, lebih sedikit dibandingkan biaya produksi dengan cara yaitu sebesar $\mathrm{Rp} 14.929 .824 / \mathrm{ha} /$ tahun. Kondisi biaya produksi akan sangat tidak ideal apabila penggunaan mesin penanam digunakan oleh satu orang petani dengan luas lahan garapan 0,1 ha, terbukti pada perhitungan pada kondisi actual mesin penanam digunakan pada lahan $1134 \mathrm{~m}^{2}$. Hasil perhitungan menunjukkan kebutuhan biaya produksi meningkat tinggi hingga mencapai Rp 3.951.953/musim tanam.

Tingginya biaya produksi apabila biaya tetap dibebankan hanya kepada satu orang petani dengan luas lahan garapan 0,1 ha menunjukkan bahwa penerapan sebuah mesin penanam di suatu desa membutuhkan keterlibatan seluruh anggota kelompok tani yang ada di dalamnya. Kondisi lainnya yang memperkuat hal tersebut adalah biaya produksi mesin per ha yang mencatatkan kebutuhan sebesar Rp 8.177.955/ha/musim tanam atau senilai dengan $\mathrm{Rp}$ 24.533.813/ha/th.

\section{Break Event Point (BEP)}

Break Event Point (BEP) dihitung untuk mengetahui seberapa luas lahan yang harus ditanam untuk mendapatkan titik impas atau kembalinya modal. BEP sendiri menunjukkan pendapatan yang diterima petani sama dengan jumlah biaya yang telah dikeluarkan.

Berdasarkan dari perhitungan Nilai BEP pada penanaman menggunakan mesin penanam adalah sebesar 0,003 ha/tahun. Dapat dikatakan bahwa penanaman menggunakan mesin penanam ini terhitung sangat menguntungkan. Nilai BEP untuk penanaman dengan cara tandur adalah nol, karena tidak adanya biaya tetap yang dikeluarkan per tahunnya. Jika dinilai dari segi titik impas ini, penamanan dengan cara tandur lebih menguntungkan karena petani tidak mengeluarkan modal terkait dengan biaya tetap.

\section{Benefit Cost Ratio (BCR)}

Perbandingan biaya dan keuntungan ditujukan untuk mengetahui kelayakan suatu usaha, apabila nilai perbandingan menunjukkan angka lebih besar dari nol maka usaha tersebut termasuk ke dalam kategori layak usaha. Berdasarkan hasil yang diperoleh dari keuntungan dan kebutuhan biaya produksi yang dibutuhkan untuk mesin penanam dihasilkan BCR 
dengan nilai 1,63/ha/tahun sedangkan cara tandur menghasilkan BCR sebesar 1,73/ha/tahun. Perolehan nilai tersebut harus didukung oleh baiknya kinerja mesin dan kualitas penanaman yang dihasilkan, karena kedua hal tersebut merupakan faktor penting untuk meminimisasi biaya dan maksimisasi keuntungan. Jika melihat pada kedua hasil tersebut, dua metode penanaman memiliki kelayakan usaha jika dilihat dari nilai BCR yang lebih dari 0, akan tetapi jika dibandingkan antara keduanya tentu cara tandur masih memiliki kelayakan yang lebih baik.

\section{Net Present Value (NPV)}

Net Present Value (NPV) dihitung untuk menganalisis selisih antara pengeluaran dan pendapatan (cash flow yang dihasilkan) pada penanaman menggunakan mesin penanam dan penanaman dengan cara tandur. Nilai pengeluaran dan pendapatan ini telah dikalkulasikan dengan discount factor. Nilai NPV menunjukkan nilai bersih dari investasi yang dilakukan

Berdasakan hasil perhitungan nilai NPV bernilai positif, yaitu sebesar Rp 92.493.315,44, menunjukkan bahwa penanaman menggunankan mesin penanam bersifat feasible atau layak untuk diterapkan. Penanaman menggunakan cara mudur juga dinyatakan feasible, karena nilai NPV yang positif bahkan dengan nilai yang melebihi penanaman menggunakan mesin tanam, yaitu mencapai $\operatorname{Rp} 110.315 .822,57$.

Apabila kedua sistem ini dibandingkan kelayakannya berdasarkan nilai NPV, penanaman dengan cara tandur dinyatakan sebagai sistem yang layak. Sistem yang memiliki nilai NPV lebih besar adalah sistem yang dinyatakan layak.

\section{Internal Rate of Return}

Perhitungan Internal Rate of Return (IRR) ditujukan untuk mengetahui kelayakan investasi pada penanaman menggunakan mesin penanam dan penananam menggunakan cara tandur. Kelayakan tersebut dapat diketahui dari perbandingan nilai IRR yang didapatkan dengan nilai discount faktor yang digunakan. IRR mengindikasikan efisiensi dari investasi yang dilakukan pada kedua sistem tanam ini. Berdasarkan hasil perhitungan, nilai IRR penanaman menggunakan mesin penanam adalah sebesar $96,89 \%$. Nilai tersebut sangat jauh berbeda dengan suku bunga bank yang digunakan yaitu sebesar 10,5\%. Hal tersebut menunjukkan bahwa penanaman menggunakan mesin penanam dapat dikatakan sangat layak untuk diterapkan (feasible) karena IRR jauh lebih besar jika dibandingkan dengan suku bunga bank yang ada. Sementara itu, nilai IRR penanaman menggunakan cara tandur menunjukkan nilai $108,82 \%$, dimana nilai ini kembali lebih besar jika dibandingkan dengan suku bunga bank yang ada dan IRR penanaman dengan mesin penanam. Nilai IRR kedua sistem penanaman ini menunjukkan bahwa kedua sistem berada dalam kondisi layak investasi karena mampu memiliki nilai lebih besar dibandingkan dengan suku bunga bank yang ada. Jika kedua sistem ini dibandingkan kelayakannya menggunakan IRR, maka penanaman dengan cara tandur dikatakan lebih layak karena persentase IRR cara ini memiliki nilai yang lebih besar.

\section{KESIMPULAN}

1. Uji kinerja mesin menghasilkan efisiensi sebesar 30,78\%, kapasitas kerja sebesar 0,04 ha/jam atau 22,12 jam/ha, kebutuhan bahan bakar 1,87 1/jam (41,35 1/ha), Nilai efisiensi dan kapasitas kerja mesin termasuk ke dalam katagori rendah, karena apabila melihat pada test report mesin mampu menghasilkan efisiensi sebesar 64,43\% dan kapasitas kerja sebesar 5,05 jam/ha atau $0,20 \mathrm{ha} / \mathrm{jam}$.

2. Analisis Kelayakan usaha tani mesin penanam mencatatkan hasil BEP 0,003/ha/tahun, NPV Rp 92.493.315, BCR 1,63, dan IRR 96,89\%, sedangkan cata tandur menghasilkan BEP 0 
/ha/tahun, NPV Rp 110.676.453, BCR 1,73, dan IRR $108,82 \%$.

\section{DAFTAR REFERENSI}

Ariyanti, R., Rahayu, S.M., dan Husaeni, A. (2014). Analisis Break Event Point sebagai Dasar Pengambilan Keputusan Manajemen terhadap Perencanaan Volume Penjualan dan Laba. Jurnal Administrasi Bisnis, 11 (1).

Badan Standardisasi Nasional. (2013). SNI 7607:2013. Mesin Tanam Bibit Padi Tipe Dorong-Syarat Mutu dan Metode Uji. Jakarta.

Herwanto, T., Handarto, dan Yusuf, A. (2016). Modul Praktikum Mesin dan Peralatan Pertanian. Fakultas Teknologi Industri Pertanian. Universitas Padjadjaran. Jatinangor.

Kartasapoetra. (1988). Teknologi Budidaya Tanaman Pangan di Daerah Tropis. Bina Aksara. Jakarta.
Kementrian Tenaga Kerja. (1999). Keputusan Menteri Tenaga Kerja, Nomor 51 tentang Nilai Ambang Batas Faktor Fisika di Tempat Kerja. Jakarta.

Regional Network of Agriculture Machinery. (1995). RNAM Test Codes and Procedures for Farm Machinery. Economic and Social Commission Asia Pacific. Bangkok.

Umar, S., Hidayat, A.D., dan Pangaribuan, S. (2017). Pengujian Mesin Tanam Padi Sistem Jajar Legowo (Jarwo Transplanter) di Lahan Rawa Pasang Surut. Jurnal Teknik Pertanian, 6(1): $63-72$.

Widata, S. (2015). Uji Kapasitas Kerja dan Efisiensi Hand Traktor untuk Pengolahan Tanah Lahan Kering. Vol. VI No.2 ISSN: 1978 - 2276. 